Original Article

Artigo Original

Kelly Cristina Alves Silverio ${ }^{1}$

Larissa Thaís Donalonso Siqueira²

José Roberto Pereira Lauris ${ }^{3}$

Alcione Ghedini Brasolotto ${ }^{1}$

Keywords

Voice

Dysphonia

Pain

Neck Pain

Pain Measurement

Descritores

Voz

Disfonia

Dor

Cervicalgia

Medição da Dor

Correspondence address:

Kelly Cristina Alves Silverio

Departamento de Fonoaudiologia,

Faculdade de Odontologia de Bauru,

Alameda Dr. Octávio Pinheiro Brisolla, 9-75,

Bauru (SP), Brasil, CEP: 17012-901.

E-mail: kellysilverio@usp.br

Received: 06/09/2014

Accepted: 07/10/2014

CoDAS 2014;26(5):374-81

\section{Muscleskeletal pain in dysphonic women}

\section{Dor musculoesquelética em mulheres disfônicas}

\begin{abstract}
Objective: To investigate the location, frequency and intensity of muscle pain in dysphonic functional/ organofunctional women in comparison to women with healthy voices. Methods: Sixty women, ranging in age from 18 to 45 years, divided into two groups: Dysphonic Group (DG) - 30 women with functional or organofunctional dysphonia; Non-Dysphonic Group (NDG) - 30 women without vocal complaints, and with adapted voices. All answered a protocol, marking the localization, frequency and intensity symptoms of pain on the temporal area, masseters, submandibular areas, larynx/pharynx, front and back of the neck, shoulders, upper back, lower back, elbows, fists/hands/fingers, hip/this, knees and ankles/feet. The volunteer should report the frequency in which pain was present in the last 12 months: no, rarely, frequently or always. The intensity of pain was measured by visual-analogue scales. The DG and NDG groups were compared using the Mann-Whitney test $(\mathrm{p}<0.05)$. Results: The women of the DG reported significantly greater frequency of submandibular area $(\mathrm{p}=0.008)$, laryngeal pain $(\mathrm{p}<0.001)$, front of the neck $(\mathrm{p}=0.015)$, back of the neck $(p=0.001)$, shoulder pain $(p=0.027)$, upper back $(p=0.027)$ and also reported significant greater intensity of pain in the larynx/pharynx $(\mathrm{p}=0.022)$ and back of the neck $(\mathrm{p}=0.003)$. Conclusion: The frequency and intensity of musculoskeletal pain was more frequent and more intense in dysphonic women than in women without vocal complaints, showing that pain may be related to functional and organofunctional dysphonia in women.
\end{abstract}

\section{RESUMO}

Objetivo: Investigar a localização, frequência e intensidade da dor muscular em mulheres com disfonia funcional/organofuncional e comparar com um grupo de mulheres com vozes saudáveis. Métodos: Participaram 60 mulheres, entre 18 e 45 anos, divididas em dois grupos: Disfônico (GD) - 30 mulheres com disfonia funcional/organofuncional; Não Disfônico (GND) - 30 mulheres sem queixas vocais, sem alterações vocais. Todas responderam a um protocolo para localização, frequência e intensidade da dor. Foram investigadas as regiões: temporal, masseteres, submandibular, laringe/faringe, parte anterior/posterior do pescoço, ombros, parte superior/inferior das costas, cotovelos, punhos/mãos/dedos, quadril/coxas, joelhos, tornozelos/pés. A voluntária deveria assinalar a frequência em que a dor esteve presente nos últimos 12 meses: não, raramente, com frequência ou sempre. Para mensuração da intensidade da dor, utilizou-se a escala visual analógica. Os grupos foram comparados pelo teste de Mann-Whitney $(\mathrm{p}<0,05)$. Resultados: As mulheres do GD relataram maior frequência de dores na região submandibular $(\mathrm{p}=0,008)$, região da laringe/faringe $(\mathrm{p}<0,001)$, parte anterior $(\mathrm{p}=0,015)$ e posterior $(\mathrm{p}=0,001)$ do pescoço, ombros $(\mathrm{p}=0,027)$ e parte superior das costas $(\mathrm{p}=0,027)$ do que as do GND; relataram dor significativamente mais intensa na laringe/faringe $(\mathrm{p}=0,022)$ e região posterior do pescoço $(\mathrm{p}=0,003)$ quando comparadas ao GND. Conclusão: A frequência e intensidade de dor musculoesquelética foram maiores e mais frequentes nas mulheres disfônicas do que nas sem queixas, revelando que a dor pode estar relacionada às disfonias funcionais e organofuncionais em mulheres.

Study carried out at the Speech Language Pathology and Audiology Department, School of Dentistry, Universidade de São Paulo - USP - Bauru (SP), Brazil.

(1) Speech Language Pathology and Audiology Department, School of Dentistry of Bauru, Universidade de São Paulo - USP - Bauru (SP), Brazil.

(2) Graduate Program in Speech Language Pathology and Audiology, School of Dentistry, Universidade de São Paulo - USP - Bauru (SP), Brazil.

(3) Department of Pediatric Dentistry, Orthodontics and Public Health, School of Dentistry of Bauru, Universidade de São Paulo - USP - Bauru (SP), Brazil.

Financial support: Fundação de Amparo à Pesquisa do Estado de São Paulo - FAPESP.

Conflict of interests: nothing to declare. 


\section{INTRODUCTION}

Some types of functional and organofunctional dysphonia may be associated with muscle changes that cause body discomfort, especially pain in the cervical area. Many classifications for dysphonia related to inadequate vocal behavior have been proposed in literature, especially concerning the symptom of excessive laryngeal muscle tension, with changes in glottal closure, vocal quality, and laryngeal structure ${ }^{(1-3)}$. The most common characteristics of these types of dysphonia are the following: excessive laryngeal and perilaryngeal muscle tension ${ }^{(1,4-7)}$, which usually leads to vocal and laryngeal changes ${ }^{(8)}$; presence of posterior glottic gap; median constriction of vocal folds and laryngeal vestibule; changes in vocal fold mucosa, with edema or nodules;larynx elevation; suprahyoid muscle tension; breathiness; brusque vocal attack; tense and strident voice; and resonance changes ${ }^{(1,2,8)}$. These aspects are more common among women, being observed in $60-70 \%$ of patients with dysphonia ${ }^{(7,8)}$, whose etiology is related to inadequate vocal behavior.

Besides, functional and organofunctional dysphonia may be related to cervical changes, such as muscle pain at rest or in movement $t^{(9,10)}$, hyperactivity of muscles involving the cervical region $^{(6,8,11,12)}$,and limited cervical motion range ${ }^{(9,10)}$. Some studies in literature focused on the investigation of vocal and laryngeal symptoms among individuals with dysphonia ${ }^{(5,8,10,13,14)}$, but the relationship between muscle pain and dysphonia is little explored $^{(10,15,16)}$, despite being clinically observed in patients with dysphonia.

As defined by the International Association for the Study of Pain ${ }^{(17)}$, "pain is an unpleasant sensory and emotional experience associated with actual or potential tissue damage, or described in terms of such damage." Many people reportpain in the absence of tissue damage or any likely pathophysiological reason; usually this happens due to psychological reasons. There is no way to distinguish these types of pain, once pain is subjective. Each person learns to use this term based on one's own experiences, and if someone refers his or her experience to be painful, it should be considered as such, even if there is no tissue damage ${ }^{(17)}$.

Some studies mention "pain when speaking" as a symptom that can be associated with gastroesophageal reflux, musculoskeletal tension dysphonia, and some laryngeal damage, such as granuloma ${ }^{(14,18)}$. But, besides pain while speaking, the person with dysphonia can also feel other types of body pain, close to the pharynx or not.

In this context, there are some more recent studies in literature that try to understand better if pain is associated with the act of speaking, even if distal to the larynx. It is possible to observe an association between pain and dysphonia, and pain has been more present among individuals who extensively use their voices in their work routine, especially among female individuals ${ }^{(15)}$. In another study ${ }^{(16)}$, the authors observed that professionals who use their voice for work reported having sore throats more frequently, as well as pain in the neck, shoulders, head, ears, and back, than those who do not work with their voices. Authors ${ }^{(16)}$ recommend that protocols of diagnosis and treatment should include the type and intensity of pain considering professionals who work with their voices and individuals with dysphonia.
Pain related to phonation among professionals who work with their voices has also been recently studied among teachers $^{(15)}$, lyrical singers ${ }^{(19)}$, teleoperators ${ }^{(20)}$, and popular singers ${ }^{(21)}$. However, only a few studies explored this question, considering functional or organofunctional dysphonia, to investigate the presence of pain and its characteristic, related to phonation or not.

Therefore, the objective of this study was to investigate the location, frequency, and intensity of muscle pain among women with functional or organofunctional dysphonia, and to compare it to a group of women with no vocal complaints, and voices considered to be healthy.

\section{METHODS}

This is an observational, cross-sectional, and prospective study.

\section{Sample}

Sixty women were selected and divided into two groups: dysphonic group (DG), composed of 30 women with functional or organofunctional dysphonia aged between 21 and 44 years (mean age: 29.06 years); non-dysphonic group (NDG), composed of 30 women with no vocal complaints, and voices considered to be healthy, aged between 19 and 37 years (mean age: 24.06 years).

In order to be in the DG, volunteers should be aged between 18 and 45 years; report complaints of vocal change; present altered voice, indicated by a previous speech language assessment; and present diagnosis of functional dysphonia (mediumposterior triangular chinks or irregular chinks associated with the presence of cysts in one of the vocal folds, associated or not with contralateral damage) or organofunctional dysphonia (bilateral vocal nodules or bilateral mucosal thickening and medium-posterior or double triangular chink), with laryngeal diagnosis shown by an otolaryngology evaluation.

In order to be in the NDG, volunteers should be aged between 18 and 45 years; have healthy voices, shown by a speech language evaluation; not present with vocal/laryngeal complains; and not have had history of constant dysphonia. Volunteers in the NDG were not submitted to laryngological assessment.

All the volunteers in the DG and NDG could not have undergone clinical or surgical, vocal or laryngeal treatment, and they could not present with hormonal or thyroid-related changes.

Chart 1showsthe professions of volunteers in groups DG and NDG, and Chart 2 shows the otolaryngology diagnosis in the DGto characterize the sample.

Chart 1. Distribution of women in the dysphonic group and in the non-dysphonic group according to profession

\begin{tabular}{|lcc|}
\hline Profession & Dysphonic group & Non-dysphonic group \\
\hline Teacher & $14(46.6 \%)$ & 0 \\
Speech language therapist & 0 & $9(30.0 \%)$ \\
Lawyer & 0 & $2(6.6 \%)$ \\
Customer service & $5(16.6 \%)$ & 0 \\
Journalist & $2(6.6 \%)$ & 0 \\
Professionals who do not & $9(30.0 \%)$ & $19(63.3 \%)$ \\
work with their voice & & \\
\hline
\end{tabular}


Chart 2. Distribution of women in the dysphonic group according to otolaryngology diagnosis

\begin{tabular}{|lc|}
\hline Otolaryngology diagnosis & Dysphonic group \\
\hline Thickening or bilateral nodules and & $16(53.3 \%)$ \\
medium-posterior triangular chink & \\
Bilateral nodulesand hourglass chink & $1(3.33 \%)$ \\
Medium-posterior triangular chink & $2(6.6 \%)$ \\
$\begin{array}{l}\text { Pseudocyst or cyst, contralateral nodule } \\
\text { reaction, and hourglass chink }\end{array}$ & $11(36.6 \%)$ \\
\hline
\end{tabular}

\section{Procedure}

All the volunteers signed the Informed Consent (CEP099/2011) approved by the research ethics committee of the School of Dentistry of Bauru, Universidade de São Paulo (FOB/USP).

Afterwards, volunteers were submitted to an investigation concerning the location, frequency, and intensity of musculoskeletal pain.

For the investigation of location and frequency of pain, the protocol Musculoskeletal Pain Questionnairewas used for this study (Appendix 1) ${ }^{(22)}$, with drawn pictures of body parts corresponding to the items to be checked. The investigated parts were temporal region, masseters, submandibular areas, larynx, front and back of the neck, shoulders, upper back, elbows, fists/hands/fingers, lower back, hip/thighs, knees, and ankles/feet. The investigation of pain regarding these body regions was based on the Nordic Questionnaire on Musculoskeletal Disorders ${ }^{(23)}$, adapted by the addition of the following parts: neck, front area; temporal region; masseters, submandibular area, and larynx (Appendix 1). In this protocol, the volunteer should mark the part in which there was pain in the past 12 months and, for each part, he or she should sign its frequency: not present, rarely, often, and always. The volunteer was advised to answer if the pain was associated to voice use.

To measure the intensity of pain, a $100-\mathrm{mm}$-long visual analog scale was used ${ }^{(24)}$, which was included in the same protocol, indicating the name of each body region. Then, for each of the pain locations, the volunteer should draw a vertical line in the scale to show the point characterizing the pain; the left end referred to no pain at all, and the right end referred to the worst possible pain. These marks were measured with a ruler, in millimeters, for posterior statistical analysis. The visual analog scale was included to quantify the intensity of pain. This is a unidimensional scale because it assesses only one of the dimensions of the painful experience, which is intensity ${ }^{(25)}$, presenting high levels of validity and reliability ${ }^{(26)}$.

\section{Data analysis}

To statistically compare the DG and NDG as to the frequency of musculoskeletal pain, as well as intensity of pain, the Mann-Whitney test was applied (0.05 significance level).

\section{RESULTS}

Tables 1 and 2 show the frequency and intensity of musculoskeletal pain, according to its location, reported by women in the DG and NDG. It is possible to observe that both frequency and intensity of pain are higher in the DG than in the NDG, with a significant difference in areas that are closer to the larynx, cervix, and scapular waist.

Table 1. Mean and standard deviation of the frequency of pain, according to its location, reported by women in the dysphonic and non-dysphonic group

\begin{tabular}{|c|c|c|c|}
\hline \multirow[t]{2}{*}{ Musculoskeletal pain } & $\begin{array}{c}\text { Dysphonic } \\
\text { group }\end{array}$ & $\begin{array}{c}\text { Non-dysphonic } \\
\text { group }\end{array}$ & \multirow[t]{2}{*}{$p$-value } \\
\hline & Mean \pm SD & Mean \pm SD & \\
\hline Temporal region & $1.57 \pm 1.19$ & $1.20 \pm 1.00$ & 0.254 \\
\hline Masseter & $1.20 \pm 1.21$ & $0.93 \pm 1.17$ & 0.374 \\
\hline Submandibular region & $0.83 \pm 1.02$ & $0.13 \pm 0.35$ & $0.008^{*}$ \\
\hline Larynx/pharynx & $1.77 \pm 1.41$ & $0.53 \pm 0.73$ & $<0.001^{*}$ \\
\hline Front of the neck & $1.47 \pm 1.36$ & $0.57 \pm 0.68$ & $0.015^{\star}$ \\
\hline Back of the neck & $2.40 \pm 1.10$ & $1.50 \pm 0.82$ & $0.001^{*}$ \\
\hline Shoulders & $2.10 \pm 1.32$ & $1.40 \pm 0.86$ & $0.027^{*}$ \\
\hline Upper back & $1.83 \pm 1.02$ & $1.23 \pm 0.77$ & $0.027^{*}$ \\
\hline Elbows & $0.37 \pm 0.72$ & $0.23 \pm 0.50$ & 0.633 \\
\hline Fists/hands/fingers & $1.03 \pm 1.10$ & $0.67 \pm 0.99$ & 0.187 \\
\hline Lower back & $1.53 \pm 1.11$ & $1.23 \pm 1.07$ & 0.358 \\
\hline Hip/thighs & $0.43 \pm 0.63$ & $0.57 \pm 0.86$ & 0.797 \\
\hline Knees & $1.00 \pm 0.91$ & $0.80 \pm 1.00$ & 0.307 \\
\hline Ankles/feet & $0.97 \pm 1.03$ & $0.60 \pm 0.81$ & 0.208 \\
\hline
\end{tabular}

${ }^{*}$ Mann-Whitney test $-\mathrm{p}<0.05$

Caption: SD = standard deviation

Table 2. Mean and standard deviation of intensity of pain, in millimeters, according to its location, reported by womenin the dysphonic and nondysphonic group

\begin{tabular}{lcccc}
\hline \multirow{2}{*}{ Musculoskeletal pain } & \multicolumn{2}{c}{$\begin{array}{c}\text { Dysphonic } \\
\text { group }\end{array}$} & $\begin{array}{c}\text { Non-dysphonic } \\
\text { group }\end{array}$ & p-value \\
\cline { 2 - 3 } & Mean \pm SD & & Mean \pm SD & \\
\hline Temporal region & $7.73 \pm 19.24$ & $2.13 \pm 6.53$ & 0.197 \\
Masseter & $6.53 \pm 17.65$ & $8.03 \pm 17.30$ & 0.889 \\
Submandibular region & $4.60 \pm 12.32$ & $1.00 \pm 5.48$ & 0.197 \\
Larynx/pharynx & $18.12 \pm 29.17$ & $2.70 \pm 7.94$ & $0.022^{*}$ \\
Front of the neck & $8.97 \pm 21.01$ & $0.37 \pm 1.65$ & 0.055 \\
Back of the neck & $18.60 \pm 27.00$ & $3.30 \pm 10.65$ & $0.003^{*}$ \\
Shoulders & $10.95 \pm 18.11$ & $4.50 \pm 10.34$ & 0.382 \\
Upper back & $14.60 \pm 21.82$ & $3.53 \pm 9.47$ & 0.051 \\
Elbows & $2.23 \pm 9.71$ & $0.00 \pm 0.00$ & 0.382 \\
Fists/hands/fingers & $5.07 \pm 12.46$ & $1.15 \pm 4.67$ & 0.197 \\
Lower back & $12.40 \pm 19.94$ & $7.90 \pm 17.14$ & 0.279 \\
Hip/thighs & $3.17 \pm 9.83$ & $0.33 \pm 1.65$ & 0.358 \\
Knees & $4.03 \pm 11.76$ & $2.37 \pm 12.78$ & 0.192 \\
Ankles/feet & $2.40 \pm 8.11$ & $2.40 \pm 9.47$ & 0.562 \\
\hline
\end{tabular}

*Mann-Whitney test $-\mathrm{p}<0.05$

Caption: SD = standard deviation 


\section{DISCUSSION}

This study chose to analyze only women, because the occurrence of dysphonia related to inadequate vocal behavior, with laryngeal damage, is more common for this gender, due to the female pattern of glottis proportion ${ }^{(27)}$ and because they are more frequent to the voice clinic.

Even though some authors ${ }^{(10)}$ stated that regardless of the presence of vocal change, women are prone to the presence of muscle pain and discomfort in the cervical region, this study aimed at investigating such pain in detail, to check if there are differences in the frequency of presence, as well as intensity of pain, among women with and without dysphonia.

Data in this study suggest that, generally, women present with pain in the cervical region and in the scapular waist, but that the frequency of pain is different among women with dysphonia and those with no vocal changes; therefore, it is more common in the laryngeal area, as well as in the neck, shoulders, and upper and lower back of women with dysphonia (Table 1).

By investigating the intensity of pain, it was possible to observe that women in the DG had more intense pain in the larynx and back of the neck than those in the NDG (Table 2). These results are in line with those of the study in which authors ${ }^{(9)}$ found a significantly higher rate of craniocervical dysfunction among women with vocal nodules when compared to women without vocal complaints. Thisimplies that women with dysphonia had more changes in cervical motion range, pain while moving or to palpation, and damaged cervical joint function.

There were no statistically significant differences between women with and without dysphonia with regard to intensity of pain in the front region of the neck and upper back (Table 2). This may be because the sample size is one of the factors that influenced such results, even though there is statistical trend that women with dysphonia presented more intense pain in these regions than those without dysphonia. The study ${ }^{(16)}$ that investigated the type and the intensity of pain during phonation among professionals who work with their voices and those who do not, involving 1,152 participants(832 professionals who used their voice and 320 who did not), revealed that $55 \%$ of those who did not use their voices and $84 \%$ of those who used their voices for work reported the presence of one or more symptoms of pain while speaking. Professionals who use their voices for work had sore throat more often, as well as pain on the neck, head, ears, and back, in comparison to those who do not use their voices in the work routine. However, only the intensity of sore throat was significantly higher among professionals who work with their voices.

The data in this study show how much musculoskeletal pain in the laryngeal, cervical, and scapular waist areas can be associated with inadequate vocal behavior. Even though this study did not aim at associating these factors by questioning the volunteer about the location, frequency, and intensity of pain, the results point out to this fact. The standarddeviation for both groups was high, which indicates dispersion of values both for frequency and for the intensity of pain. This fact may be explained because pain is subjective, and each person interprets it differently, because it depends on the person's own experiences ${ }^{(17)}$.

The more frequent pain in the submandibular region, larynx, and the front of the neck, as well as the intense pain in the larynx, is very specific and more common in the population of women with dysphonia, which shows that women with organofunctional or functional dysphonia present muscle pain in that region as a characteristic of dysphonia. This fact can be associated with muscle rigidity and imbalance of extrinsic laryngeal muscles, which are clinically observed as being part of dysphonia due to vocal abuse and intensive voice use. However, the presence of more intense pain in regions that are close to the larynx, which can be related to inadequate vocal behavior, requires the attention of the speech language pathologist when caring for women with dysphonia and musculoskeletal pain. Pain can be an aggravating factor, which leads to compensatory adjustments with inadequate body postures and unwanted muscle tensions, to prevent more intensive pain, thus perpetuating the pain and dysphonia.

Other authors ${ }^{(10)}$ verified the relationship between dysphonia and muscular and skeletal changes in women, and also found reports of significantly more frequent laryngeal pain among womenwith dysphonia than in those without dysphonia. However, authors did not find significant differences between the dysphonic and the control groups when comparing the presence of musculoskeletal pain in the area of neck and shoulders, with self-reported pain in both studied groups. The authors did not investigate the frequency, but instead, the pain to palpation of the cervical muscle (trapezius muscle), upper fibers, back of the neck, and sternocleidomastoid muscles; they did not find differences between women with dysphonia and those without vocal complaints.

One of the limitations of this study was that the analyzed groups were heterogeneous with regard to profession, once the vocal demand can influence muscle activity and, consequently, frequency and intensity of pain. Another limitation of this study was that vocal, health, and physical exercise habits were not investigated, as well as posture at work and at rest, which may have an impact on muscle activity and tonicity. By observing the presence of more intense and more frequent musculoskeletal pain in cases of dysphonia related to vocal behavior, it is necessary to explore the previously mentioned aspects to better understand pain in dysphonia.

Even though this study did not analyze the relationship between muscle pain and the professional use of voice, it is possible to state that the profession can be one of the risk factors for the development of dysphonia and muscle pain, because, in the sample, $30 \%$ of the DG and $63.3 \%$ of the NDG did not use their voices for work purposes, and did not use their voices constantly at work. However, $46.6 \%$ of the DG comprised teachers (Chart 1). Studies that aimed at investigating the relationship between muscle pain and intensive voice use found significant results among professionals who work with their voices ${ }^{(28)}$. The authors ${ }^{(28)}$ tried to identify 
and characterize the presence of body pain among men and women and to relate it with data related to voice and reported vocal problems. They observed that female and male individuals presented body pain during and/or after using their voice for work, and this occurrence was more frequent for women. Other authors ${ }^{(15)}$ studied the prevalence of musculoskeletal pain according to sociodemographic and occupational variables of teachers in elementary school, involving 4,496 teachers in the municipal network of Salvador (BA), Brazil. The authors observed that the prevalence of musculoskeletal pain in the lower limbs ("leg pain," 41.1\%), upper limbs ("arm pain," 23.7\%), and back ("back/spinal pain," $41.1 \%$ ) was high. Musculoskeletal pain was more prevalent among women; older people, with average schooling; married people with three or more children;and who had worked for more than 14 years as teachers. The prevalence of musculoskeletal pain was associated with the following occupational variables: more than 5 years of work in the analyzed school, physical exertion, a different paid activity unrelated to teaching and heat in the classroom. Further studies may investigate the relationship of musculoskeletal pain among teachers, but considering the specific body parts related to the constant use of voice, such as the cervical and the laryngeal regions, as analyzed in this study.

The results in this study corroborate the findings in literature, which reveal that muscle pain in the cervical region can be strongly associated with dysphonia ${ }^{(9,29)}$. This study is also in accordance with the recommendations found in other analyses, which observed relationships between muscle pain and intensive use of voice, not necessarily dysphonia, in which the presence of muscle pain should be considered in the assessment of the individual ${ }^{(28)}$. At the presence of dysphonia, this investigation should be detailed and include not only the location and the frequency of pain, but also its intensity, especially in the cervical and laryngeal areas, because it was significantly higher among women with dysphonia. Finally, the findings in this study contribute with the different knowledge, suggesting that the treatment of pain in speech language therapy should be considered in cases of functional and organofunctional dysphonia, to promote analgesia and muscle relaxation, with consequent improvement in vocal treatment.

\section{CONCLUSION}

Women with functional and organofunctional dysphonia present with muscle pain in the submandibular area, larynx, front and back of the neck, shoulders, and upper back more frequently, as well as the more intense pain in the larynx and the back of the neck, when compared to women with no vocal changes.

\section{ACKNOWLEDGMENT}

The authors acknowledge the support provided by the São Paulo Research Foundation (FAPESP) for this study, processnumber 2010/19470-9.
*KCAS participated in the study design, in the execution of evaluations, data interpretation and elaboration of the manuscript; LTDS participated in the execution of evaluations, data interpretation and elaboration of the manuscript; JRPL executed data analysis; AGB participated in the study design, data interpretation and critical review of the study. All of the authors approved the final manuscript.

\section{REFERENCES}

1. Rubin JS, Blake E, Mathieson L. Musculoskeletal patterns in patients with voice disorders. J Voice. 2007;21(4):477-84.

2. Morrison MD, Rammage LA. Muscle misuse voice disorders: description and classification. Acta Otolaryngol. 1993;113(3):428-34.

3. Morrison MD, Rammage LA, Belisle GM, Pullan CB, Nichol H. Muscular tension dysphonia. J Otolaryngol. 1983;12(5):302-6.

4. Aronson AE. Clinical voice disorders: an interdisciplinary approach. $3^{\text {rd }}$ edition. New York: Thieme; 1990.

5. Colton RH, Casper JK. Compreendendo os problemas de voz - uma perspectiva fisiológica ao diagnóstico e ao tratamento. Porto Alegre: Artes Médicas; 2000.

6. Hsiung MW, Hsiao YC. The characteristic features of muscle tension dysphonia before and after surgery in benign lesions of the vocal fold. ORL J Otorhinolaryngol Relat Spec. 2004;66(5):246-54.

7. Zheng YQ, Zhang BR, Su WY, Gong J, Yuan MQ, Ding YL, et al. Laryngeal aerodynamic analysis in assisting with the diagnosis of muscle tension dysphonia. J Voice. 2012;26(2):177-81.

8. Angsuwarangsee T, Morrison M. Extrinsic laryngeal muscular tension in patients with voice disorders. J Voice. 2002;16(3):333-43.

9. Bigaton DR, Silvério KCA, Berni KCS, Distefano G, Forti F, Guirro RRJ. Postura craniocervical em mulheres disfônicas. Rev Soc Bras Fonoaudiol. 2010;15(3):329-34.

10. Menoncin LCM, Jurkiewicz AL, Silvério KCA, Camargo PM, Wolff NMM. Alterações musculares e esqueléticas cervicais em mulheres disfônicas. Arq Int Otorrinolaringol. 2010;14(4):461-66.

11. Behrman A. Common practices of voice therapists in the evaluation of patients. J Voice. 2005;19(3):454-69.

12. Imamura R, Domingos H. Disfonia espasmódica de adução, tremor vocal e disfonia de tensão muscular: é possível fazer o diagnóstico diferencial? Rev Bras Otorrinolaringol. 2006;72(4):434.

13. Altman KW, Atkinson C, Lazarus C. Current and emerging concepts in muscle tension dysphonia: a 30-month review. J Voice. 2005;19(2):261-7.

14. Roy N, Nissen SL, Dromey C, Sapir S. Articulatory changes in muscle tension dysphonia: evidence of vowel space expansion following manual circumlaryngeal therapy. J Commun Disord. 2009;42(2):124-35.

15. Cardoso JP, Ribeiro IQB, Araújo TM, Carvalho FM, Reis EJFB. Prevalência de dor musculoesquelética em professores Rev Bras Epidemiol. 2009;12(4):604-14.

16. Van Lierde KM, Dijckmans J, Scheffel L, Behlau M. Type and severity of pain during phonation in professional voice users and non vocal professionals. J Voice. 2012;26(5):671e19-23.

17. International Association for the Study of Pain (IASP) (2013) [Internet]. IASP Taxonomy [cited 2013 May 16]. Available from: http://www.iasppain.org/Education/Content.aspx?ItemNumber=1698\#Pain

18. Behlau M, Feijó D, Pontes P. Disfonias por refluxo gastresofágico. In: Behlau M. Voz: o livro do especialista. Volume 2. Rio de Janeiro: Revinter; 2005.

19. Vaiano T, Behlau M, Guerrieri AC. Treinamento vocal pode ser fator protetor contra dores. In: $18^{\circ}$ Congresso Brasileiro de Fonoaudiologia; 2010. Set 22-25. Curitiba. Anais. Disponível em: http://www.sbfa.org.br/ portal/anais2010/anais_select.php?op=buscaresultado\&cid=3886\&tid=1

20. Constancio S, Moreti F, Guerrieri AC, Behlau M. Dores corporais em teleoperadores e sua relação com o uso da voz em atividades laborais. Rev Soc Bras Fonoaudiol. 2012;17(4):377-84.

21. Rocha C, Moraes M, Behlau M. Dor em cantores populares. J Soc Bras Fonoaudiol. 2012;24(4):374-80.

22. Kuorinka I, Jonsson B, Kilbom A, Vinterberg H, Biering-Sørensen F, Andersson G, et al. Standardised Nordic questionnaires for the analysis of musculoskeletal symptoms. Appl Ergon. 1987;18(3):233-7. 
23. Pinheiro FA, Tróccoli BT, Carvalho CV. Validação do Questionário Nórdico de Sintomas Osteomusculares como medida de morbidade. Rev Saúde Pública. 2002;36(3):307-12.

24. Scott J, Huskisson EC. Graphic representation of pain. Pain. 1976;2(2):175-84.

25. Jensen MP, Karroly P, Braver S. The measurement of clinical pain intensity: a comparison of six methods. Pain. 1986;27(1):117-26.

26. Lima Neto EV, Goldenberg A, Jucá MJ. Resultados imediatos da herniorrafia inguinal com anestesia local associada com sedação. Acta Cir Bras. 2003;18(5):478-84.
27. Behlau M, Madazio G, Feijó D, Ponte P. Avaliação de voz. In: Behlau M. Voz: o livro do especialista. Volume 1. Rio de Janeiro: Revinter; 2001.

28. Guerrieri AC, Behlau M. Presença de dores corporais relacionadas ao uso da voz em indivíduos do sexo masculino e feminino. In: $16^{\circ}$ Congresso Brasileiro de Fonoaudiologia; 2008. Set 24-27. Campos do Jordão. Anais. Disponível em: http://www.sbfa.org.br/portal/anais2008/ resumos/R0363-1.pdf

29. Roy N, Mauszycki SC, Merrill RM, Gouse M, Smith ME. Toward improved differential diagnosis of adductor spasmodic dysphonia and muscle tension dysphonia. Folia Phoniatr Logop. 2007;59(2):83-90. 
Appendix 1. Questionário de Investigação de Dor Musculoesquelética

\section{Questionário de Investigação de Dor Musculoesquelética}

Nome:

Nascimento:

Profissão: Outra atividade com uso da voz

Com base na figura humana abaixo, você deverá registrar a frequência em que tem sentido dor, dormência, formigamento ou desconforto nas regiões numeradas no desenho do corpo.

Suas opções de respostas são as obtidas na escala a seguir:
(0) Não
(1) Raramente
(2) Com frequência
(3) Sempre

Exemplo:

Considerando os últimos 12 meses, você têm tido algum problema (tal como dor, desconforto ou dormência) nas seguintes regiões:

Se você tem sentido dores no pescoço com frequência, você deverá assinalar o número 2

\begin{tabular}{|lllll}
\hline 1. Pescoço? & 0 & 1 & 2 & 3 \\
\hline
\end{tabular}

Referências visuais sobre a localidade das regiões a serem avaliadas:

Parte I

Parte II
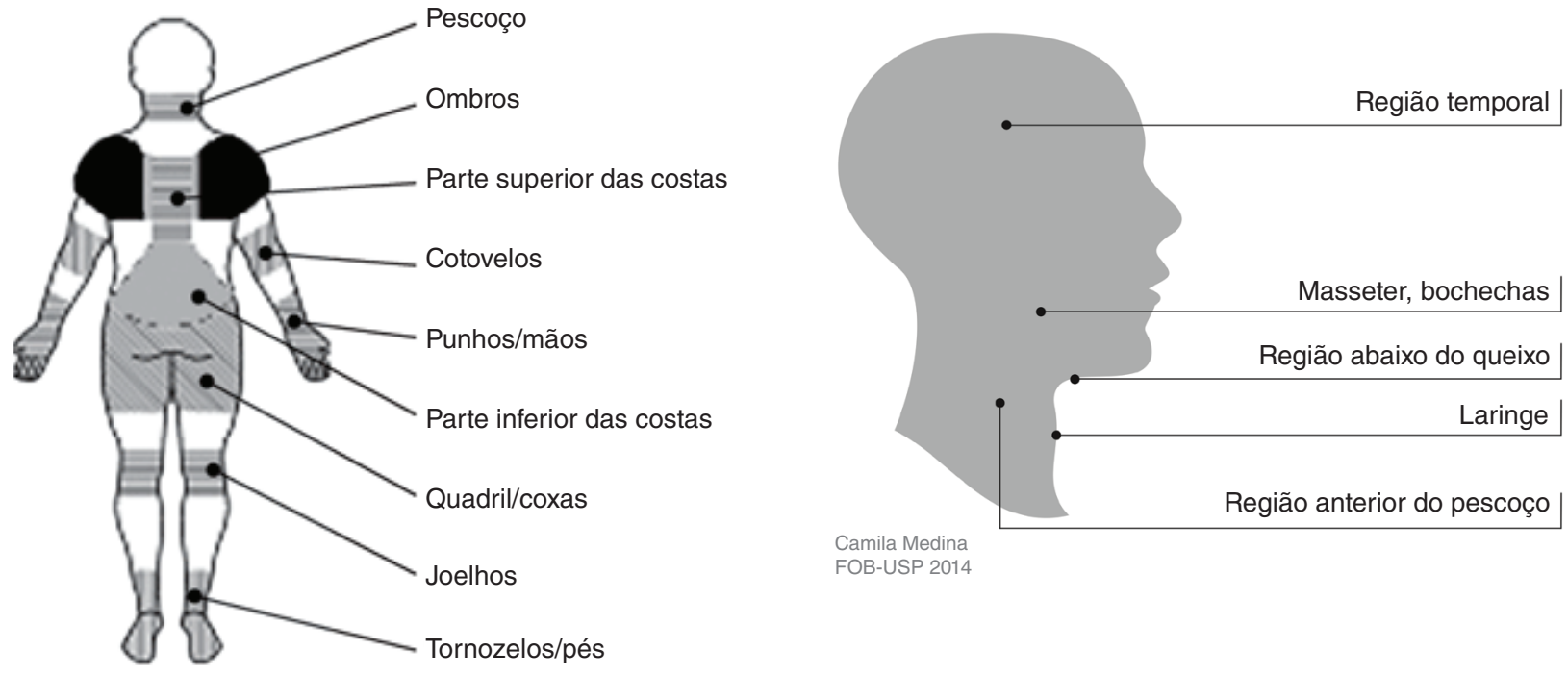

Camila Medina

FOB-USP 2014

continue... 
Appendix 1. Continuation

Considerando os últimos 12 meses, você tem tido algum problema (tal como dor, desconforto ou dormência) nas seguintes regiões:

Parte I
1. Pescoço
(0) Não
(1) Raramente
(2) Com frequência
(3) Sempre
2. Ombros
(0) Não
(1) Raramente
(2) Com frequência
(3) Sempre
3. Parte superior das costas
(0) Não
(1) Raramente
(2) Com frequência
(3) Sempre
4. Cotovelos
(0) Não
(1) Raramente
(2) Com frequência
(3) Sempre
5. Punhos/mãos
(0) Não
(1) Raramente
(2) Com frequência
(3) Sempre
6. Parte inferior das costas
(0) Não
(1) Raramente
(2) Com frequência
(3) Sempre
7. Quadril/coxas
(0) Não
(1) Raramente
(2) Com frequência
(3) Sempre
8. Joelhos
(0) Não
(1) Raramente
(2) Com frequência
(3) Sempre
9. Tornozelos/pés
(0) Não
(1) Raramente
(2) Com frequência
(3) Sempre

Parte II
1. Região temporal
(0) Não
(1) Raramente
(2) Com frequência
(3) Sempre
2. Masseter, bochechas
(0) Não
(1) Raramente
(2) Com frequência
(3) Sempre
3. Região abaixo do queixo
(0) Não
(1) Raramente
(2) Com frequência
(3) Sempre
4. Laringe
(0) Não
(1) Raramente
(2) Com frequência
(3) Sempre
5. Região anterior do pescoço
(0) Não
(1) Raramente
(2) Com frequência
(3) Sempre

\section{Intensidade da dor}

Assinale na reta abaixo a intensidade da dor que você sente:

Pescoço:

Ombros:

Parte superior das costas:

Cotovelos:

Punhos/mãos:

Parte inferior das costas:

Quadril/coxas:

Joelhos:

Tornozelos/pés:

Região temporal:

Masseter, bochechas:

Região abaixo do queixo:

Laringe:

Região anterior do pescoço:

$\begin{array}{lr}\text { Nenhuma dor } & \text { Pior dor possível } \\ \text { Nenhuma dor } & \text { Pior dor possível } \\ \text { Nenhuma dor } & \text { Pior dor possível } \\ \text { Nenhuma dor } & \text { Pior dor possível } \\ \text { Nenhuma dor } & \text { Pior dor possível } \\ \text { Nenhuma dor } & \text { Pior dor possível } \\ \text { Nenhuma dor } & \text { Pior dor possível } \\ \text { Nenhuma dor } & \text { Pior dor possível } \\ \text { Nenhuma dor } & \text { Pior dor possível } \\ \text { Nenhuma dor } & \text { Pior dor possível } \\ \text { Nenhuma dor } & \text { Pior dor possível } \\ \text { Nenhuma dor } & \text { Pior dor possível } \\ \text { Nenhuma dor } & \text { Pior dor possível } \\ \text { Nenhuma dor } & \text { Pior dor possível }\end{array}$

